Maurice A. Deane School of Law at Hofstra University

Scholarly Commons at Hofstra Law

Hofstra Law Faculty Scholarship

$10-29-2013$

\title{
The Pregnancy Discrimination Act Reaches Advanced Maternal Age
}

Joanna L. Grossman

Maurice A. Deane School of Law at Hofstra University

Follow this and additional works at: https://scholarlycommons.law.hofstra.edu/faculty_scholarship

\section{Recommended Citation}

Joanna L. Grossman, The Pregnancy Discrimination Act Reaches Advanced Maternal Age Verdict (2013) Available at: https://scholarlycommons.law.hofstra.edu/faculty_scholarship/986

This Article is brought to you for free and open access by Scholarly Commons at Hofstra Law. It has been accepted for inclusion in Hofstra Law Faculty Scholarship by an authorized administrator of Scholarly Commons at Hofstra Law. For more information, please contact lawlas@hofstra.edu. 


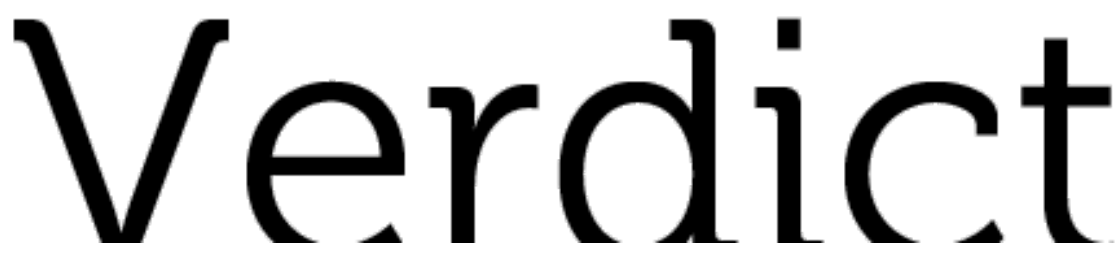

October 29, 2013

Joanna L. Grossman

\section{The Pregnancy Discrimination Act Reaches Advanced Maternal Age}

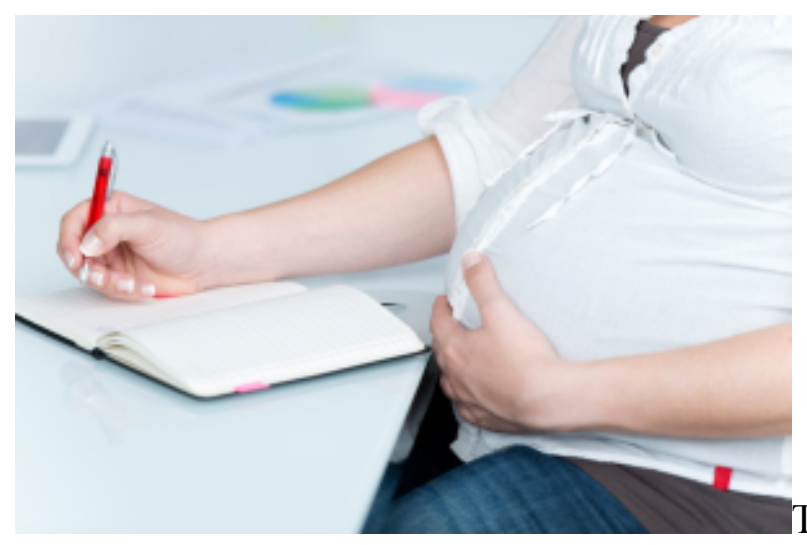

This week marks the 35th anniversary of the passage of the Pregnancy Discrimination Act (PDA) of 1978. Signed into law on Halloween that year by President Jimmy Carter, the PDA was instrumental in ending a longstanding era of the lawful exclusion of pregnant women from the workforce. The Act ushered in an era of unprecedented access for women to jobs before, during, and after pregnancy. This was, and still is, cause for celebration. Yet, pregnant workers today continue to face high levels of discrimination and, more importantly, to lack some basic legal protections that are necessary to enable some women to continue working throughout pregnancy.

In human years, thirty-five is a turning point when "advanced maternal age" sets in, and most conversations with one's obstetrician start with "Well, because of your age, we need to. ..." It marks the beginning of the end of one's fertility and the increase in the likelihood of pregnancy complications and fetal abnormalities.

We might say that the PDA has reached a similar stage. After a robust start, in which the PDA was effectively used to eliminate the most common types of policies and decisions used to exclude women from the workplace entirely or marginalize their participation, attorneys and the women they represent have together struggled in recent years to ensure that the PDA is useful to the pregnant workers whom it should benefit. The complication here is not, of course, the biological clock, but, rather, the mindset of judges, who cannot give the Act its due, and who perhaps feel that its time is done and gone. But we should not stop pushing for pregnant workers' rights until those workers have been been fully integrated into the workplace, and do not suffer discrimination.

\section{The PDA: The Early Years}

The PDA was enacted to reverse the Supreme Court's 1976 ruling in General Electric Co. v. Gilbert (http://supreme.justia.com/cases/federal/us/429/125/case.html), in which the Supreme Court had held that pregnancy discrimination was not a form of sex discrimination and therefore not unlawful under Title VII. The same reasoning prompted the Court, two years earlier in Geduldig v. Aiello

(http://supreme.justia.com/cases/federal/us/417/484/case.html), to hold that pregnancy discrimination was not a form of sex discrimination for equal protection purposes. Together, these rulings meant that governmental entities and private employers were free to openly discriminate against pregnant women by refusing to hire them, forcing them to quit upon becoming pregnant, or changing the conditions of employment in any way that suited the employer. They reinforced the legality of widespread and explicit discrimination against pregnant workers. 
The only protection for pregnant women at that time arose from a 1974 ruling in Cleveland Board of Education v. LaFleur (http://supreme.justia.com/cases/federal/us/414/632/case.html), in which the Court held that, as a matter of due process, public employers could not conclusively presume pregnant women to be incapable of work without allowing for proof of individual levels of capacity.

The first clause of the PDA amended Title VII, the main federal anti-discrimination law, to make clear that discrimination on the basis of "pregnancy, childbirth, or related medical conditions" is unlawful. This spelled the end of the most common exclusionary policies and provided a basis for challenging employment decisions based on bias against pregnant women or the application of stereotypes about their competence or abilities. (This latter point was suggested by LaFleur, but constitutional due process rights had no impact on private employers.) Pregnant women had a right to work on the same terms as everyone else as long as they were capable of doing their jobs despite the pregnancy.

But while the first clause of the PDA was effective in opening workplace doors to pregnant women, it does little to help women to the extent that pregnancy actually interferes with their work capacity, completely or partially. Pregnancy discrimination under this clause is only prohibited if it is the product of animus against a pregnant worker, or reflects stereotyped views about her abilities or competence. A pregnant woman who actually cannot perform some aspect of her job because of pregnancy-related disability can be fired or otherwise penalized for that limitation.

\section{Conflicts Between Pregnancy and Work}

Although there is no inherent conflict between pregnancy and work, many women will encounter at least minor conflicts during pregnancy or post-childbirth (not to mention that they will need to be away from work while childbirth takes place). The conflicts can involve environmental hazards like exposure to chemicals or other toxins that are especially or only harmful to pregnant women; physical limitations like lifting restrictions; or conditions of work like irregular shifts, long periods of standing, the inability to eat or drink during a shift, and insufficient bathroom breaks. These conflicts sometimes give rise to a need for accommodations, many of which are minor and costless - and yet nevertheless are denied to pregnant workers by their employers.

Indeed, current federal law does not insist that employers provide accommodations to enable a woman to continue working through her pregnancy, and permits employers to fire employees who suffer a full or partial, but temporary, loss in capacity due to pregnancy, subject only to the very minimal protection provided by disparate impact law. The pregnancy-discrimination framework, which ties rights to capacity, fails to account for the actual effects of pregnancy on women's bodies and work capacity, and thus fails to meet the needs of many pregnant working women today, especially those who labor in non-traditional jobs that can be physically strenuous or hazardous.

These conflicts are increasing as women enter the workforce in greater numbers; enter traditionally maledominated occupations that are more likely to include physical demands; work more and longer into pregnancy; and come back to work sooner after childbirth. Moreover, both the likelihood of conflicts and the consequences of refusing to accommodate them are greater for women at the lower-end of the wage scale, where one finds jobs with more physically-demanding tasks or jobs with rigidly-structured work settings - and employers who provide less generous benefits. Thus, while the PDA offers some protection against animus-based discrimination, it has become increasingly unhelpful to those women whose pregnancies are most likely to harm their economic security.

\section{The Second Clause of the PDA: Comparative Accommodations?}

These increasing and real conflicts have put pressure on the second clause of the PDA, which provides that pregnant women have the right to be treated the same as others but others who are "similar in their ability or inability to work." It is this clause that has been the subject of many recent cases; even now, thirty-five years after the law's passage, its meaning is not universally understood.

By its terms, the second clause of the PDA provides, at best, a comparative right of accommodation. It does not 
give pregnant women any absolute right to have pregnancy-related disability accommodated with leave or modifications to the job. Instead, it creates a comparison group to whom pregnant women can compare themselves to gauge their possible entitlement to an accommodation. If no one gets benefits or accommodations, pregnant women have no right to them either. But, the straightforward language of the second clause would suggest, if temporarily disabled workers receive accommodations, then pregnant women must also receive them.

Early on, the Supreme Court ruled that the second clause of the PDA does not, in fact, require identical treatment between those with pregnancy-related disability and those with comparable disability from other causes. In $\underline{C a l}$ Fed v. Guerra (http://supreme.justia.com/cases/federal/us/479/272/), the Court held that the PDA sets a floor, not a ceiling, on the benefits or accommodations that might be provided to pregnant workers. Thus, a state could mandate maternity leave without mandating disability leave, or an employer could voluntarily provide leave or accommodations to pregnant workers without providing them to anyone else. The limit on benefits is that they must correspond to the actual period of disability related to pregnancy, and cannot be used to provide parenting leave only for women.

\section{The PDA and Discriminatory Light-Duty Policies}

In the last decade, there have been a number of lawsuits raising new questions about the scope and meaning of the second clause of the PDA. The focus of these lawsuits has been the legality of employer policies that provide light-duty assignments to workers who are injured or disabled on the job, but not to those who are injured off the job. These policies do not, by their words, exclude pregnancy, but they are drawn in a manner such that workers with pregnancy-related disability cannot obtain light-duty accommodations. This is so even when the workers who do receive light-duty accommodations are, in every way, "similar [to pregnant women] in their ability or inability to work."

Despite the obvious violation of the PDA's second clause, several federal appellate courts have upheld on-the-job light-duty policies. For the most part, women challenging light-duty policies have been unsuccessful unless they are able to show discriminatory intent. Instead of following the plain language of clause two, requiring pregnant workers to be treated as well as other workers "similar in their ability to work," lower courts are increasingly demanding evidence of a discriminatory intent lurking behind such policies before striking them down.

\section{A typical light-duty case is Reeves v. Swift Transportation Co. (http://law.justia.com/cases/federal/appellate-} courts/F3/446/637/554813/) Amanda Reeves was an over-the-road truck driver for Swift Transportation. When Reeves applied for the job, she represented that she could lift seventy-five pounds (sixty over her head) and carry it for fifty-six feet. After three months on the job, Reeves discovered she was pregnant. She had never, up to that point, had to unload a truck herself or carry anything heavy. Her doctor wrote a note restricting her to light work, which included lifting no more than twenty pounds. Her supervisor reviewed the note, declared that they had no "light work" for her to do, and sent her home. Although the company had light-duty assignments, it refused to give them to her because her limitations were not the result of an on-the-job injury. The company eventually fired her for failing to work at full capacity.

In her PDA lawsuit, Reeves argued that the light-duty policy was per se discriminatory because no pregnant woman could qualify for light work, regardless of whether her level of incapacity was the same as workers who did qualify. The court rejected this theory, ignored the existence of a formal policy that violated the second clause, and demanded proof of pretext or discriminatory intent. As long as the policy was pregnancy-blind, the court held, it did not violate the PDA.

By defining the comparison pool for pregnant workers to exclude a favored class of workers (such as those injured on the job), courts construe pregnant workers' requests for light-duty work as a demand for "special treatment." Under such an analysis, the employer gets to choose the relevant comparison group for which to establish that the pregnant woman has received the same treatment as those similar in their ability or inability to work, as long as the choice is not animated by discriminatory intent. By permitting the employer to pick and choose among comparably disabled workers, the court fundamentally misconstrues clause two of the PDA, which by its terms entitles pregnant women to work on the same terms as more favorably treated workers who are similarly restricted in their capacity to work. 
A recent case, Young $v$. United Parcel Service, Inc. illustrates how this approach is now effectively nullifying the second clause of the PDA. Peggy Young was hired by UPS in 1999. She began driving a delivery truck for the company in 2002. As an "air driver," charged with delivering packages that came via air rather than ground delivery, Young typically carried lighter letters and packs. Young's job description, however, required her to be able to lift and maneuver packages weighing up to 70 pounds, and assist with movement of packages up to 150 pounds. Young was covered by a collective bargaining agreement (CBA), which required UPS to provide temporary, light-duty work assignments to employees who could not perform their regular jobs due to an on-thejob injury. The CBA also extended light-duty work to drivers who are legally prohibited from driving because they either failed a required medical exam or lost their driver's license. Beyond the requirements of the CBA, UPS had a policy to permit light-duty assignments when "an employee has a qualifying disability within the meaning of the ADA which prevents him/her from being able to perform some aspects of his/her job." Because women with pregnancy-related disability do not fall into any of these categories, they are "permitted to continue working as long as they wanted to during their pregnancies, unless and until the employee presented a doctor's note or other medical certification that she had a restriction that rendered her unable to perform the essential aspects of the job."

When Young became pregnant, her doctor wrote a note recommending that she lift no more than 20 pounds during the first half of her pregnancy and no more than 10 pounds thereafter. The company decided that it could not allow her to continue working since she was not capable of performing the lifting described in the list of essential job functions for her position. Having used up all available medical leave for infertility treatments, she was put on a leave of absence with no pay and no medical coverage.

Young filed a lawsuit, which was dismissed by a federal district court at the summary judgment stage. The dismissal was upheld by the Court of Appeals for the Fourth Circuit. The appellate court held that Young was not entitled to accommodations granted the other groups of workers, despite having a similar need for light duty. Young was not permitted to use anyone who was eligible for ADA accommodation or had lost their legal ability to drive as a comparator in the PDA claim. Nor could she compare herself to a worker injured on the job because she was not similarly situated based on the source of injury. Although the Fourth Circuit acknowledged that second clause of the PDA "can be read broadly," it chose not to give it such effect. Instead, it expressly rejected the idea that the second clause of the PDA creates "a distinct and independent cause of action" and refused to transform "an antidiscrimination statute into a requirement to provide accommodation to pregnant employees, perhaps even at the expense of other, nonpregnant employees."

The type of reasoning upon which the Fourth Circuit relied is the death knell for the right of comparative accommodation. It effectively allows employers to revert to a pre-PDA world, in which they can single out pregnancy among other disabilities for adverse treatment. This is precisely what the PDA was enacted to eliminate. And reasoning like the Fourth Circuit's is only going to be more harmful as an amended version of the ADA gets interpreted to provide accommodations to a greater and greater number of disabled employees. Soon, there will be no one left to whom a pregnant worker can point when she is trying to enforce her comparative right of accommodation.

\section{Restoring Protection for Pregnant Workers: Next Steps}

Peggy Young has petitioned for certiorari to the Supreme Court. Although the Court has not yet ruled on the petition, it recently invited the Solicitor General to submit a brief on whether it should hear the case. Given that the Fourth Circuit's ruling in Young, conflicts in significant ways with the Court's prior PDA precedents, one hopes that the Court would use the case to restore the prior robustness of the law. If not, the pressure will be on Congress to override the Court — as it has done many times in the last two decades on civil rights issues - or to enact a new law that expressly provides reasonable accommodation for pregnancy-based disability.

The Pregnant Workers' Fairness Act, which I have written about here (http://verdict.justia.com/2012/05/11/thepregnant-workers-fairness-act), has been introduced and would require employers to accommodate pregnancyrelated disability as long as doing so would not impose an undue hardship on employers. Several states and cities, including, most recently, New York City, have passed their own versions of a reasonable accommodation law. 
There are many possible avenues to provide greater protection for pregnant workers, but something must be done.

Joanna L. Grossman, a Justia columnist, is the Sidney and Walter Siben Distinguished Professor of Family law at Hofstra University. She is the coauthor of Inside the Castle: Law and the Family in 20th Century America (Princeton University Press 2011), co-winner of the 2011 David J. Langum, Sr. Prize for Best Book in American Legal History, and the coeditor of Gender Equality: Dimensions of Women's Equal Citizenship (Cambridge University Press 2009). Her columns focus on family law, trusts and estates, and sex discrimination. Follow @JoannaGrossman

Posted In Employment Law

Access this column at http://j.st/ZQJY

(C) 2011-2014 Justia :: Verdict: Legal Analysis and Commentary from Justia ::

\section{JUSTIA}

The opinions expressed in Verdict are those of the individual columnists and do not represent the opinions of Justia

Have a Happy Day! 